\title{
PERKEMBANGAN DAN EKSISTENSI HUKUM ADAT: DARI SINTESIS, TRANSPLANTASI, INTEGRASI HINGGA KONSERVASI ${ }^{1}$
}

\author{
Ridwan', Prof. Dr. H. Khudzaifah Dimyati, S.H.,M.Hum. ${ }^{2}$, Dr. Aidul Fitriciada Azhari, S.H.,M.Hum. ${ }^{3}$ \\ ${ }^{1}$ Mahasiswa PDIH Sekolah Pascasarjana \\ ${ }^{2}$ Guru Besar Fakultas Hukum \\ ${ }^{3}$ Magsiter Ilmu Hukum \\ Universitas Muhammadiyah Surakarta
}

\begin{abstract}
$T$ The aim of this study is to determine the pattern of development of customary law in Bima and its existence after the reform, so that the known tendency. This type of research is non-doctrinal, or socio legal (qualitative), with a historical approach, data used consist of primary data and secondary data. Results of the study are; (1) the development pattern of customary law Bima there are, a) Synthesis law, ie when the customary law and Islamic law met and complementary, and there is no confrontation between them, $b$ ) Transplant law, occurs when the system of colonial law pushed into local arrangements with limit the authority of the judiciary Islam, which led to the legal vacuum, c) Integration of the law, when the central government to build the legal political uniformity through codification and unification, d) Positive law, namely when the reform was blowing, spirit locally formed through regulations, (2) the existence of customary law that there is complete loss, and surviving, surviving customary law is found in Donggo community, with all the flexibility and various forms of sanctions uniqueness.
\end{abstract}

Keywords: Development Pattern, Existence, Customary Law

\begin{abstract}
Abstrak
$T$ ujuan dari penelitian ini adalah untuk menentukan pola perkembangan hukum adat di Bima dan keberadaannya setelah reformasi, sehingga kecenderungan dikenal. Jenis penelitian ini adalah non-doktrinal, atau sosial hukum (kualitatif), dengan pendekatan historis, data yang digunakan terdiri dari data primer dan data sekunder. Hasil dari penelitian ini adalah; (1) pola perkembangan hukum adat Bima ada, a) hukum Sintesis, yaitu ketika hukum adat dan hukum Islam bertemu dan saling melengkapi, dan tidak ada konfrontasi antara mereka, b) hukum Transplantasi, terjadi ketika sistem hukum kolonial didorong ke pengaturan lokal dengan batas kewenangan peradilan Islam, yang menyebabkan kekosongan hukum, c) Integrasi hukum, ketika pemerintah pusat untuk membangun keseragaman politik hukum melalui kodifikasi dan unifikasi, d) hukum positif, yaitu pada saat reformasi bertiup, semangat lokal dibentuk melalui peraturan, (2) adanya hukum adat yang ada kerugian lengkap, dan yang masih hidup, yang masih hidup hukum adat ditemukan di masyarakat Donggo, dengan semua fleksibilitas dan berbagai bentuk sanksi.
\end{abstract}

Kata Kunci: Pola perkembangan, Eksistensi, dan Hukum adat

1 Ringkasan Tesis Pada Program Studi Magister Ilmu Hukum Program Pascasarja Universitas Muhamamdiyah Surakarta tahun 2012. 


\section{Pendahuluan}

Kelahiran negara modern sejak abad 7 dan 8 yaitu masa feodalisme, terus tumbuh dan berkembang melewati abad-abad ke 12, 15, 17 sampai puncaknya pada abad 19 dengan konsep rule of law (common law system), rechstaaat (civil law system) dan negara konstitusional, perkembangan ini juga berbarengan dengan sejarah sosial budaya negara eropa, Eropa Barat khususnya, yakni merangkak dari dark-ages, middle ages, renaisancce 'pencerahan' dan akhirnya sampai ke abad modern. ${ }^{2}$ Maka sejak itu hukum memasuki hampir sekalian ranah kehidupan manusia dan membangun bentuk ketertiban yang di kehendakinya, hampir tidak ada ranah kehidupan yang tidak di atur oleh model hukum ini, ia melakukan proteksi dalam kehidupan manusia. Kehidupan penuh dengan desain, tidak ada lagi yang berjalan alami dan mandiri, hukum pelan-pelan mengiris kehidupan manusia, mulai dari ranah ekonomi, kesehatan, pendidikan, sosial budaya, hingga keluarga di iris-iris sesuai dengan potongan-potongan yang di kehendakinya. Kenyataan dan kebenaran sekalipun di konstruksi mengikuti kemauan dan kehendak rezim yang disebut dengan 'paradigma modern' tersebut.

Dalam logika hukum modern yang di anggap hukum adalah keputusan badan-badan yang berwenang, di luar itu tidak di anggap hukum, kecuali secara jelas memperoleh legalitas dari hukum negara, pranata-pranata yang telah ada sebelumnya seperti kearifan lokal atau hukum adat (hukum Islam) hanya akan berlaku apabila hukum negara tegas memberi izin untuk itu. ${ }^{3}$

Indonesia sebagai negara yang mengadopsi sistem hukum modern lewat aneksasi dan transplantasi kultural yang berlangsung lebih dari satu abad (1840-1950), yang kemudian berlanjut dengan proses modifikasi serta adaptasinya ${ }^{4}$ sangat sulit untuk dengan begitu saja keluar dari kungkungan hukum itu, sebaliknya malahal semakin menguat mensuboordinasi pranata lain di luar yang di kehendakinya.

Hukum modern menjadikan kodifikasi dan unifikasi sebagai strategi implimentasinya, hukum di buat seseragam mungkin dan berlaku menyeluruh, imbasnya kemudian tidak saja terjadinya perubahan struktur dan sistem penegakan hukum, namun juga berimplikasi pada dinamika hukum lokal yang tumbuh dan berkembang di tengah-tengah masyarakat. Masyarakat Indonesia di desak dan di paksa untuk menerapkan hukum yang jauh bahkan berbeda sama sekali dengan budaya dan kultur mereka, negara-negara berkembang seperti Indonesia harusnya tidak bisa di paksakan cara-cara penyelenggaraan hukum yang mapan seperti di barat. ${ }^{5}$ Sebab setiap bangsa, memiliki basis cultural sendiri-sendiri.

Setelah terlibat lama dalam "ritual pengagungan' atas hukum modern'(hukum positif) ini Indonesia ternyata harus berbagi ketidakbahagian, karena justru hukum modern (paradigma positivistik) yang di berlakukan di seluruh Nusantara malah menjadi 'beban pranata lokal' ${ }^{6} \mathrm{di}$ sana sini hukum di rasakan menjadi beban berat, malah merupakan benda asing bagi sebagin rakyat, dan seringkali hukum modern menjadi pemicu chaos. Belum lagi janji-janji hukum modern seperti justice for all malah yang di saksikan justive not for all, ${ }^{7}$ kegagalan hukum menjadi tontonan yang sangat marak, keadilan menjadi barang langka, tindakan main hakim sendiri seakan mengindikasikan hidup tanpa terikat hukum, pada beberapa kasus koruptor Berjaya dengan menggunakan lembaga peradilan sebagai tameng, pada saat yang sama rakyat

2 Satjipto Rahadjo, Biarkan Hukum Mengalir: Catatan Kritis Tentang Pergulatan Manusia dan Hukum, Jakarta: Penerbit Kompas, 2007, hlm. 106.

3 Rahardjo, Satjipto, Dalam Khudzaifah Dimyati (ed), 2004, Ilmu Hukum: Pencarian Pembebasan dan Pencerahan, Surakarta: Muhammadiyah Univesity Press Ubiversitas Muhammadiyah Surakarta. hlm. 24.

4 Soetandyo Wignjosoebroto, Dari Hukum Kolonial Ke Hukum Nasional: Dinamika Sosial-Politik Dalam Perkembangan Hukum Indonesia, Jakarta: PT. Raja Grafindo Persada, edisi 1-cetakan kedua1995, hlm. 111.

$5 \quad$ Khudzaifah Dimyati, Teorisasi Hukum: Studi Tentang Perkembangan Pemikiran Ilmu Hukum Di Indonesia 1945-1990, Yogyakarta: Genta Publishing, cetakan kedua 2010, hlm. 99.

6 Rahadjo, Satjipto, Penegakan Hukum Progresif, Jakarta: Kompas, 2010, hlm. 6, lihat juga disertasinya Bernard L. Tanya, Hukum Negara Menjadi Beban Masyarakat Lokal.

$7 \quad$ FA. Adji Samekto, Justice Not For All: Kritik Terhadap Hukum Modern Dalam Perspektif Studi Hukum Kritis, Yogyakart: Genta Press, 2008, hlm. 12. 
kecil dilahap habis oleh hukum, kondisi demikian memunculkan sikap kritis rakyat masihkah kita mempertahankan sistem hukum yang demikian "buruk" itu?

Setelah berberapa perubahan rezim, terutama lahirnya orde reformasi, menjadi momentum terpenting atas pencarian akan sebab pemicu kegagalan hukum, untuk itu minat untuk mengoreksi kembali paradigma mainstream pembangunan hukum menjadi sesuatu yang tidak terhindarkan. Tidak sedikit para ahli, profesional dan pakar mensinyalir kegagalan hukum di Indonesia di sebabkan oleh bangsa ini telah meninggalkan filosofi bangsa sendiri. ${ }^{8}$

Hadirnya Reformasi 1998 menjadi satu momentum terpenting terhadap masa depan kearifan lokal (hukum adat), dimana dengan terjadinya desentralisasi kekuasaan daerah berhak mengangkat kekayaan-kekayaan lama termasuk hukum adat untuk dijadikan sebagai pengatur dan perekat kehidupan sosial, di perkuat oleh fenomena menarik, sejak tahun 1960-an di dunai Internasioal muncul gerakan untuk kembali ke adat sebagai antitesis atas modernitas.

Bima-NTB menjadi obejek yang menarik untuk mengoptik, tergerusnya, bahkan geliat kembangkitan kembali pranata lokal, terutama pasca reformasi lewat berbagai kebijakan kepala daerah. Fenomena ketergerusan dan kebangkitan ini sekaligus menjadi suatu hal yang menarik untuk melihat pola perkembangan dan hukum adat Bima dari jaman kerajaan sampai sekarang dan eksistensinya, serta seperti apa kecenderungannya, hal inilah yang menjadi urgensinya penelitian ini, penelusuran ini menjadi penting ditengah suasana semangat pembangunan hukum nasional dan konsolidasi desentralisasi melalui otonomi daerah, apalagi seperti yang diungkapkan di muka, semakin hari studi atas nilai-nilai luhur bangsa semakin menjadi kebutuhan untuk pembangunan sistem dan tata hukum nasional yang beridentitaskan Indonesia, atau yang pancasilais, yang berketuhanan, kemanusiaan, keadilan, dan permusyawaratan, bukan membangun hukum yang berlandaskan semangat indentitas bangsa lain yang liberalis, individualis, apalagi bangsa yang pernah menyakiti masyarakat Indonesia berabad-abad lamanya, bukan berarti kita menutup diri dengan kebenaran yang datang dari luar, namun menjadi masalah ketika bangsa ini melahap dan menelan mentah-mentah sistem Bangsa lain di tengah kekayaan bangsa sendiri yang melimpah, apa lagi sistem bangsa orang itu sudah tebukti sampai saat sekarang tidak mampu berbuat banyak untuk menghadirkan kestabilan setidaktidaknya sebagai tujuan akhir paradigma itu.

Berdasarkan gambaran pada latar belakang di atas, masalah dalam penelitian ini adalah Bagaimanakah pola perkembangan hukum adat Bima serta eksistensinya hingga kini? Adapaun tujuan peneltian ini adalah, untuk mengetahui pola perkembangan hukum adat Bima, dan mengetahui eksistensinya serta bagaiman kecenderungannya.

\section{Metode Penelitian}

Jenis penelitian ini adalah penelitian nondoktrinal atau tipologi penelitian socio legal reseach ${ }^{9}$ dengan pendekatan sejarah (approach historys), Lokasi penelitian dilakukan di Kabupaten Bima Propinsi NTB. Data yang di butuhkan adalah data lapangan sebagai data utama dan di tunjang data kepustakaaan. Analisis melalui tiga cara yaitu; reduksi data (data reduction), penyajian data (data display), penarikan kesimpulan dan verifikasi(conclusion sdrawing/verivication) atau dengan penafsiran (hermeneutik).

Teori yang digunakan dalam memotret sekaligus menganalisis objek kajian adalah Mazhab sejarah dari Carl von Savigny (Volksgeist) merupakan antitesis dari mazhab positifistik, dalam ajaran positifistik sumber hukum merupakan norma hasil kesepakatan dari pemegang kekuasaan, diluar itu tidak dianggap sebagai hukum, sementara Von Savigny menyatakan hukum kebiasaan atau hukum adat-lah yang merupakan sumber hukum formal. Hukum tidak dibuat melainkan tumbuh dan berkembang bersama-sama dengan masyarakat. Dalam paham positivisitk baru

8 Effendi, Sofian, 2010, Reformasi Tata Kepemerintahan: Menyiapakan Aparatur Negara Untuk Mendukung Demokratisasi Politik dan Ekonomi Terpadu, Yogyakarta: Gajah Mada University Press.

9 Soetandyo W, Penelitian Hukum: Sebuah Tipologi, Majalah Masyarakat Indonesia Tahun Ke1, No, 1974, hlm. 4. 
dikatakan sebagai hukum manakala mendapat sifat deklaratif dari hukum negara, sementara menurut mazhab postivisitk, tanpa di legalisasi oleh negara sekalipun hukum itu tatap berlaku dan sah bagi masyarakat pendukungnya. Theo Hujaiber menyatakan: "Menurut F. von Savigny hukum merupakan salah satu faktor dalam kehidupan bersama suatu bangsa, seperti bahasa, adat, moral, tatanegara. Oleh karena itu hukum adalah sesuatu yang bersidat supra-indiidual, suatu gejala masyarakat. Tetapi suatu masyarakat lahir dalam sejarah. Nyatalah hukum yang termasuk masyarakat itu serta dalam perkembangan organis itu. Lepas dari masyarakat tidak terdapat hukum sama sekali". ${ }^{10}$

Von Savigny menegaskan inti ajarannya, bahwa hukum itu tidak di buat, tetapi tumbuh dan berkembang bersama masyarakat. Savigny menyatakan bahwa di dunia ini terdapat banyak bangsa, dan tiap-tiap bangsa memiliki suatu 'volksgeist' jiwa rakyat. Jiwa ini berbeda, baik menurut waktu maupun tempat, pencerminannya nampak pada kebudayaan masing-masing yang berbeda-beda, hukum yang bersumber dari jiwa rakyat ini, oleh karena itu hukum itu akan berbeda pada setiap tempat dan waktu, tidaklah masuk akal terdapat hukum yang universal dan abadi. Selanjutnya Von Savigny menyatakan bahwa apa yang menjadi isi hukum itu di tentukan oleh pergaulan hidup manusia dari masa-kemasa, hukum berkembang dari suatu masyarakat sederhana yang tercermin pada setiap tingkah laku individu-individu kepada suatu masyarakat yang kompleks dimana kesadaran hukum masyarakat nampak pada ucapan-ucapan para ahli hukumnya. Jiwa ini contoh hukum kebiasaan Germania yang beraneka ragam.

\section{Pembahasan}

\section{Pola Perkembangan Hukum Pada Masyarakat Bima}

\section{a. Sintesisasi Hukum}

Sebelum Islam masuk, di Mbojo (Bima), sebelumnya telah adat tatanan kehidupan yang teratur, yaitu diawali dengan kehidupan jaman naka, lalu jaman federasi ncuhi-ncuhi (desa-desa), kesepakatan federasi ncuhi-ncuhi inilah yang kemudian menjadi embrio hukum adat pada masa kerajaan. Jaman Fase kerajaan kira-kira sejak abad ke XI M-1640 M.

Dalam mitologi orang Bima nama Bima itu sendiri merupakan nama seorang bangsawan dari Jawa yang menyatukan ncuhi-ncuhi. Kesepakatan-kesepakatan dan kebiasaan-kebiasaan jaman ncuhi itulah yang menjadi emrio lahirnya hukum adat. Untuk diketahui bahwa hukum adat yang ada sebelumnya itu di pengaruhi oleh ajaran Hindu-Budha, namun masyarakat Bima sendiri memiliki kepecayaan pada animisme. Itu artinya bahwa pranta seosial termasuk cara berhukum pada masyarakat Bima pada waktu itu menggunakan cara-cara animism walau saat yang sama ada pengaruh Hindu-budha, namun pengaruh Hindu dan budha itu tidak begitu kuat. Hal ini sesuai dengan temuan Denys Lombat yang menyatakan bahwa Hindhu dan Budha itu pengaruhnya yang kuat hanya sampai Jawa dan Bali.

Ketika Islam masuk di Bima pada tanggal 5 juli 1640 masehi, tidak lama kemudian menjadi dasar sistem pemerintahan dan pedoma kehidupan sosial masyarakat, kehadiran Islam ini kemudian tidak serta merta menghapus kebiasaan dan tatanan masyarakat yang ada sebelumnya terutama masalah hukum, perjumpaan kedua entitas ini tidak mengalami ketegangan yang cukup berarti sehingga menimbulkan gejolak sosial, namun yang terjadi malah sebaliknya, di mana kedua entitas ini saling berpadu dan melengkapi antara satu sama lain. Bukti keterpaduan hukum adat dan hukum Islam itu dapat dijumpai mulai dari bentuk pemerintahan, lembaga peradilan, sampai pada filosofi kehidupan. ${ }^{11}$

10 Theo Huijbers, Filsafat Hukum, op.cit., hlm. 118.

11 Bentuk pemerintahan dari sistem kerajaan menajdi sistem berbentuk kesultanan, sumber penegakan hukum di ambil dari hukum adat dan hukum Islam, filosofi hidup seperti ' maja labo dahu' (malu dan takut) merupakan perpaduan adat dan ajaran Islam. 
Perjumpaan kedua hukum tersebut itulah yang disebut sebagai pola perkembangan sintesis. Menggunkan term dialektika Hegel, ${ }^{12}$ tesisnya adalah hukum adat sebagai hasil konstruksi kebudayaan, antitesisnya adalah hukum Islam, sintensisnya adalah perjumpaan kedua entitas ini. Tidak ada satu literaturpun yang dapat menunjukkan, bahwa era ketika Islam masuk mengalami 'konflik' dengan nilai Hindu-Budha yang sedikit tidak telah mempengaruhi kebiasaan hidup masyarakat Bima sebelumnya. Justur pada umunya proses 'Islamisasi' berjalan baik, aman, dan tidak terdapat riak-riak yang bersifat konfrontatif. ${ }^{13}$ sehingga muncul ungkapan 'adat bersendikan sara, sara bersendikan kitabullah', ungkapan itu dan sistem pemerintahan kesultanan sebagai bentuk penyatuan atas dua kutub yang berbeda, kondisi itulah yang dianggap sebagai sintesis.

Berbeda sekali dengan islamisasi yang terjadi di wilayah lain seperti di Sumatera Barat misalnya yang terjadi konfrontasi antara hukum adat dan hukum Islam sehingga harus melahirkan consensus kedua kekuatan. Kemudian di Jawa juga terjadi pola sinkretisasi antara kebudyaan lama dengan Islam. Sinkretik di Jawa dapat dijumpai dalam ketegangan menerapkan hukum adat di satu sisi dan menerapkan hukum Islam pada sisi yang lain, agama datang ke Jawa dan Madura menawarkan tiga kelembagaan peradilan agama, yakni 'tauliyah' dari imam, bentuk 'tauliyah' dari 'ahli al haalli wal al aqdi' dan bentuk 'taqlim', bentuk-bentuk ini menunjukkan agama Islam tidak menyuguhkan konsep peradilan perspektif hukum Islam. Dengan kata lain Islam tidak menyiapakan suatu perangkat peradilan. ${ }^{14}$

Sebagaimana diketahui bahwa Jawa adalah daerah yang sangat kuat pengaruh HinduBudha sebelum Islam masuk, karenanya Denys Lombard membagi periodesasi peradaban jawa kedalam tiga golongan, yakni dari era zaman Hindu-Budha, Islamisasi, dan zaman modern dengan proses oksidentalisasi. ${ }^{15}$ Konflik antara hukum sialm dan adat ini kemudian juga di perkuat oleh Penelitian Daniel S. Lev mengemukakan bahwa konflik antara adat dan Islam merupakan tema pokok dari 'budaya politik dan hukum' di Indonesia (terutama Jawa: pen), sekalipun pemerintah mengakui adat, Islam dan hukum modern sebagai unsur dalam sistem hukum nasional. Dengan kata lain koeksistensi dari hukum adat dan pelaksanaannya, praktik-praktik tradisional, dan hukum tertulis menunjukkan adanya pluralisme hukum. ${ }^{16}$

\section{b. Transplantasi Hukum}

Setelah sekian Kesultanan Bima menjalankan hukum Islam, yang dijalankan oleh sebuah lembaga yang bernama Mahakah Syar'iyah sampai tahun 1908, namun selepas tahun 1908 ketika kolonial Belanda merangsek ${ }^{17}$ ke dalam sistem pemerintahan kesultanan Bima, perkara pidana di alihkan kepada majelis 'rapat besar', "rapat tengah" dan 'rapat rendah.' Hukum Islam tidak di terapkan lagi pada tindak pidana pembunuhan, pidana perzinahan, penghinaan atau penganiayaan, dan sejak saat itu pula dimulainya sistem kepenjaraan di Bima. Sebelum sistem kepenjaraan itu dimulai para terpidana di buang ke Pulau Komodo yang terletak di sebelah utara timur Laut Sape. Bahkan pulau itu menjadi tempat pembuangan pelaku kejahatan politik, orang yang dipandang ekstrim. ${ }^{18}$ Akibat pengalihan system hukum

12 Theo Huijbers, Filsafat Hukum Dalam Lintasan Sejarah, Yogyakarta: Kanisius, 1982, hlm. 110.

13 Jurdi, Syarifuddin, Islam, Masyarakat Madani Dan Demokrasi Di Bima: Membangun Demokrasi Kultural Yang Berbasis Religius, Yogyakarta: CNBS, 2007, hlm. 116.

14 Abdul Gani Abdullah, op.cit., hlm. 24.

15 Denys Lombard, Bagian I, op.cit., hlm. xv.

16 Jawahir Thontowi, op,.cit., hlm. xxxvii.

17 Hilir Ismail, Muhammad, Menggali Pusaka Terpendam: Butir-Butir Muatiara Budaya Mbojo, Bima: Makalah tidak diterbitkan, 2004, hlm. 10.

18 Lihat Rodney Needham "Principle and Variation in The Sosial Claassificatin of Komodo" dalam Bijdragen tot de taal-, land- en volkenkunde., deal 142, le Faris Publication Holland/USA 1986 halaman 54. Lihat pula Bezemer TJ. (editor), Beknopte Encylopaedia van Nederlandsche- Indie; Batavia; koft-, tahun 1921, hlm. 
dan peradilan itu maka terjadilah kekosongan hukum, namun kesadaran hukum masyarakat Bima terhadap pelaksanaan hukum Islam tidak mengalami pergeseran. Interfensi kolonial ini dapat disebut sebagai transplantasi hukum dan merupakan pola perkembangan hukum adat Bima yang kedua.

Lalu ketika pendudukan Jepang tahun 1942 sampai 17 Agustus 1945, tidak terlalu mempengaruhi penegakan hukum di Bima. Kesempantan ini malah Kesultanan Bima menggunakan untuk menghidupkan kembali lembaga peradilan Islam sebelumnya. Fase di Awal Kemerdekaan kesultanana Bima membentuk kembali Badan Hukum Syara' melalui 'beslit' (keputusan) No. 42 tanggal 4 Mei 1947. Keberadaan Badan Hukum Syara' dipandang orang Bima sebagai muara dari langkah modernisasi Mahkamah Syar'iyah. ${ }^{19}$

\section{c. Integrasi Ke Hukum Nasional}

Dalam perjalanannya sesuai dengan kebijakan politik hukum nasional yang menghendaki adanya penyeragaman sistem penyelenggaraan peradilan, lewat politik hukum yang dikenal dengan kodivikasi dan univikasi akhirnya Badan Hukum Sara di marger ke lembaga-lembaga vertikal pemerintahan pusat, dan Badan Hukum Sara sendiri menjadi Yayasan Islam hingga kini, fenomena ini dapat dikatakan sebagai proses terintegrasinya Bima dalam tatanan nasional termasuk tatanan hukum.

\section{d. Positivisasi Hukum Lokal}

Kejatuhan orde baru tahun 1998 memicu banyak perubahan, termasuk peruban peta politik, hukum dan sistem sosial lainnya. Di bidang hukum hadirnya orde reformasi menjadi peluang besar terangkatnya kearifan lokal (hukum adat) lewat berbagai kebijakan politik. Pada saat yang sama juga terlihat kemauan untuk melakukan positivisasi kearifan lokal yang pernah diberlakukan pada era sebelum daerah ini terintegarasi secara penuh, dimana setelah terhapusnya 'Badan Hukum Sara' sabagai lembaga representasi kearifan lokal segala sistem sosial, nilai, kekuasaan, dan organisasi.

Gerakan-gerakan di tingkat internasional telah menginspirasi kemunculan gerakan masyarakat adat di Indonesia, terutama pasca reformasi, ${ }^{20}$ muncul komunitas adat yang tergabung dalam gerakan Aliansi Masyarakat Adat Nusantara (AMAN) yang bertujuan mendesak pemerintah untuk memperhatikan budaya. Adat istiadat nusantara terutama sekali menghormati hak-hak adat. lahirnya reformasi 1998 diikuti dengan kebijakan yang tidak lagi sentralisitik dengan diberlakukannya desetralisais lewat otonomi daerah memberikan peluang kepada daerah untuk menentukan arah kebijakan pembangunan daerah dengan mengoptimalkan potensi sumberdaya daerah sebagai bagian dari sistem perencanaan pembangunan nasional.

Momentum reformasi menjanjikan begitu besar peluang untuk merawat ataupun memelihara dan mengembangkan serta merevitalisasi kearifan lokal (hukum adat), dengan harapan dapat menjadi peneguh jati diri daerah atau suatu bangsa menuju kehidupan bermasyarakat yang harmonis, aman, damai, dan sejahtera. Sebagaimana kita ketahui, bahwa tenggelamnya kearifan lokal (lokal wisdom) selama ini tidak lepas dari kebijakan sentralisasi pada waktu Orde Baru.

Terbukanya peluang untuk mengangkat kearifan lokal itu lewat peraturan daera, dan lewat kebijakan-kebijakan kepala daerah hasil dari pengejewantahan visi dan misi politik yang kemudian tertuang dalam rencana pembangunan jangka panjang dan jangka menengah

254. Dalam, Abdul Gani Abdullah, Peradilan Agama Dalam Pemerintahan Islam Di Kesultannan Bima (1947-1957), Mataram: Lengge. 2004, hlm. 155-156.

19 Ibid

20 Jamie S. Davidson dan David Henley, In the Name of Adat: Regional Perspectives on Reform, Tradition, and Democracy in Indonesia, Modern Asian Studies, 2008, hlm. 815-852. Dalam Cambridge University Press, Printed in the United Kingdom, http://search.proquest.com, di akses pada tanggal, 10 Mei 2012. 
(RPJP dan RPJM). Pada saat yang sama muncul fenomena globalisasi dan glokalisasi hukum, dimana antara hukum global dan hukum lokal, selain saling mendominasi, juga saling mengisi dan mengadopsi. Hukum internasional menjangkau wilayah lokal, sebaliknya tidak sedikit hukum lokal di adopsi oleh hukum internasional.

Di Kabupaten Bima ada beberapa produk politik yang mencerminkan semangat kearifan lokal yang pernah berlaku masa silam, langkah awal kebijakan pemerintah daerah untuk menghidupkan kembali adat Bima adalah lahirnya Perda Kabupaten Bima Nomor. 12 tahun 2001 tentang pemberdayaan lembaga adat. Dalam Perda tersebut mengamanatkan pembentukan lembaga adat mulai dari tingkat desa, kecamatan, sampai pada tingkat kabupaten. Lalu perhatian terhadap kearifan lokal ini juga teridentifikasi lewat RPJMD dan RPJPD, Perda No.7 tahun 2005 tentang RPJPD 2006-2025, dan perda No. 8 tahun 2005 tentang RPJMD tahun 2006-2010. Perda No. 6 tahun 2002 tentang larangan pelacuran.

Bentuk lain produk politik yang mengangkat kearifan lokal adalah keluarnya perda larangan pelacuran, kemudian dikeluarkannya Instruksi Bupati tentang kewajiban berjilbab, kewajiban berjilbab ini sekarang sudah termuat dalam perada tentang pengelolaan dan pelasanaan pendidikan, yang juga di dalamnya memuat kewajiaban melaksanakan Baca Tulis Qur'an (BTQ) bagi siswa pada semua tibgkatan sekolah. perda ini diangap sebagai modernisasi Budaya Rimpu masyarakat Bima yang sampai sekarang masih di pertahankan di beberapa tempat. Lalu keluar juga perdat tentang zakat, selanjutnya lahir perda No. 2 tahun 2003 tentang jum'at khusu'. Perda ini mengamanatkan, pada setiap hari juma'at mulai pukul 11.00 siang sampai jam 13.00 (tiga belas) witeng atau siang, seluruh elemen masyarakat tidak diperbolehkan melaksanakan aktifitas, karena pada waktu itu ada kewajiban sholat jum'at secara berjamah bagi mereka yang diwajibkan oleh ajaran agama Islam. Selain itu muncul Perda anti miras.

Untuk dapat mewujudkan cita-cita perda kearifan lokal yang telah di jadikan produk politik tersebut, maka keluar pula perda No. 5 tahun 2008 tentang pedoman pembentukan lembaga kemasyarakatan desa, yang di dalamnya juga mengamanatkan pembentukan lembaga adat tingkat desa. Perda ini menggantikan perda No. 10 Tahun 2002 tentang pedoman pembentukan lembaga kemasyarakatan, perda tersebut kemudian ditindak lanjuti dengan Peraturan Bupati No. 6 tahun 2009 tentang petunjuk pelaksanaan perda No. 5 tahun 2008 tentang pedoman pembentukan lembaga kemasyarakatan desa, Dengan perda tersebut di amanatkan di setiap desa dapat dibentuk lembaga adat. Dari berbagai kebijakan itu akhirnya pemerintah daerah menetapkan lima desa pilot projek lembaga adat.

\section{Esksistensi Hukum Adat Bima Hinggga Kini}

Dari upaya positivisasi bahkan sebelum terpositivisasinya kearifan lokal (hukum adat) oleh pemerintah daerah tersebut, ada desa-desa yang sudah hilang sama sekali hukum adat, ada juga beberapa segi hukum adat yang merangkak di beberapa desa, walau negara tidak lagi menghendaki berlakunya kearifan loka (hukum adat) pasca diakuisisinya Badan Hukum Sara menjadi Yayasan Islam, dan ada juga komunitas masyarakat yang di sebut masyarakat donggo yang smapai saat ini konsisten mempertahankan keberlakuan hukum adat Bima.

Kemunculan, penguatan hukum adat itu terjadi setelah reformasi. Reformasi menyebabkan kontrol rezim militer terhadap kekuatan masyarakat melemah, pada saat yang sama kekuatan masyarakat mengorganisir diri termasuk pemerintah tingkat desa semakin menguat, pada umumnya sisa-sisa hukum adat yang masih dipraktekkan dan berpengaruh itu terutama di bidang agama. Di beberapa desa juga yang terlihat masih mempraktekkan hukum adat. Dari hasil penelusuran dan wawancara yang dilakukan dibeberapa desa yang masih memperlakukan kearifan lokal (hukum adat), faktor politik atau kemampuan kepala desa menjadi faktor yang sangat penting, sebab beberapa pelanggaran yang sering muncul di tengah masyarakat pihak aparat kepolisian atau pengadilan pada kasus-kasus tertentu menginginkan adanya peran serta 
masyarakat terutama tokoh-tokoh masyarakat atau tokoh adat untuk mengambil bagian dalam menyelesaikan pelanggaran hukum yang terjadi di lingkungan masing-masing.

Satu-satunya basis komunitas masyarakat yang konsistensi mempertahankan hukum adat, yaitu masyarakat Donggo yang di jalankan oleh lembaga adat dan sari'at masyarakat Donggo (LASDO), dengan segala kelenturanya, dengan berbagai bentuk sanksinya mulai dari diberi nasehat, diperingatkan, dinikahkan secara paksa, di pukul bahkan di baja (arak keliling). Mereka mempertahankan hukum adat akibat langsung dari kuatnya daya tanah komunitas itu dari pengaruh luar, dan adanya semacam konsesus yang berjalan secara alamiah antara lembaga penegak hukum (polisi) dengan lembaga adat setempat.

Hukum adat di Donggo mampu bertahan dengan segala kelenturannya, mimiliki sanksi sendiri ketika terjadi pelanggaran, mulai dari di nasehati dan membuat pernyataan tidak mengulangi, dinikahkan bagi yang berduaan bukan muhrim, penetapan denda dan mengembalikan barang yang diterapkan pada hampir semua pelanggaran, dipukul untuk kasus zina, pencurian, dan beberapa bentuk pelanggaran dan kejahatan lainnya, di Baja ${ }^{21}$ (arak-arak keliling) adalah jenis hukuman psikis sekaligus fisik, dikenakan pada mereka yang melakukan zina, pemerkosaan, pencabulan, pencurian dan kenakalan remaja yang sudah berulang kali yang melanggar surat pernyataan tidak mengulangi yang dibuat sebelumnya, baja juga merupakan jenis hukuman yang dibarengi dengan denda dan pengembalian barang pada kasus pencurian dan pengerusakan harta benda.

Pada saat di arak pelaku sambil menerikaan kata-kata "e ringapo dou doho di rasa e aina karawi bunesantika rakarawi nahuke, nahu kasumpahkara watira karawi waliku" (dengarkanlah wahai seluruh warga jangan kalian melakukan perbuatan seperti perbuatan yang saya lakukan ini, dan saya bersumpah tidak akan mengulanginya lagi). Bagai mereka yang tidak puas atas sanksi adat yang diberikan maka adat memperbolehkan untuk melanjutkan kasus tersebut lewat jalur hukum positif, kalau kasus perdata di gugat ke pengadilan, kalau kasus pidana dilaporkan ke polisi.

Mencermati kebertahanan hukum adat Donggo ditengah dominasi kekuatan hukum modern (hukum positif) akibat langsung dari dukungan struktur dan infrastruktur negara menimbulkan satu pertanyaan besar, apakah Kebertahanana Hukum Adat Donggo: Konservasi Atau Resistensi ? Untuk menjawab pertanyaan besar tentang kebertahanan hukum adat di Donggo itu kita harus kembali memahami, bahwa secara resmi sesungguhnya negara tidak pernah meridhoi kehadiran hukum lain dalam politik pembangunan dan penegakan hukum nasional kecuali hukum positif, klaim ini diperkuat dengan paradigma pembangunan hukum nasional yang mengandalkan kodivikasi dan univikasi, logika paradigma ini jelas-jelas tidak mengijinkan adanya pluralisme hukum dalam satu rumah besar yang bernama Indonesia. Walau sebenarnya UUD 1945 dan beberapa ketentuan peraturan perudang-undangan sedikit membuka peluang untuk menghadirkan hukum adat dalam proses penyelesaian persoalan ditengah masyarakat.

Namun kenyataaannya hukum adat seakan sama sekali tidak punya tempat yang layak untuk eksis, buktinya adalah banyak sekali riset yang menunjukkan betapa aparat penegak hukum, seperti polisi, jaksa dan hakim mengesampingkan peranan hukum adat, Namun sebagai bentuk sikap pragmatisme pemerintah (penegak hukum) tidak jarang juga pada kasus dan daerah tertentu mengakui pluralisme hukum, seperti hasil riset Jawahir Thantowi tentang 'siri' di Sulawesi Selatan. hasil riset tersebut memperlihatkan, memang negara masih memberi ruang untuk eksisnya sumber-sumber hukum lain, selain hukum modern, seperti hukum adat dan hukum Islam, namun dominasi salah satu hukum tidak bisa dihindari, hukum nasional pada sisi tertentu lebih dominan dalam masyarakat Makassar. ${ }^{22}$

21 Bagi orang Bima 'Baja' (diarak keliling kampung) juga disebut kamaja (dipermalukan di hadapan umum).

22 Thontowi, Jawahir, Hukum Kekerasan Dan Kearifan Lokal Penyelesaian Sengketa Di Sulawesi Selatan, Yogyakarta: Pustaka Fahima, 2007, hlm. 380. 
Dalam kaitannya dengan kebertahanan hukum adat Bima (khususnya di komunitas masyarakat Donggo), memang pada era reformasi terjadi positivisasi (pembentukan lembaga adat) lewat peraturan daerah oleh pemerintah daerah, namun itu terjadi pada tingkatan organisasi (structur) dan tidak di ikuti dengan konsolidasi yang kuat dengan aparat pengak hukum lainnya, serta tidak dikuti dengan political will penganggaraannya yang sehat, dan seakan lembaga adat itu dibiarkan berjalan seadanya, buktinya lima desa pilot project hampir sebagian besarnya tenggelam dalam ketidak pastian.

Kemudian ada fenomena consensus secara alami antara lembaga penegak hukum (polsek setempat) dengan lembaga adat dalam penyelsesaiaan menyelesaian persoalan tertentu, konsensus alamiah tersebut bukan atas dasar kesadaran politik para penegak hukum, namun tidak lebih sebagai bentuk sikap pragmatis aparat yang merasa terbantu dengan eksisnya lembaga adat. Lagi pula tidak mudah bagi masyarakat agraris seperti komunitas mayarakat Donggo yang mendiami dataran tinggi untuk bisa menerima secara penuh logika hukum modern (hukum positif), dimana mereka sudah terbiasa mempertahankan tatanan adat kebiaasaan yang menjadi pemandu (a guide), pemersatu kehidupan mereka selama ini.

\section{Penutup}

Memperhatikan hasil dari pembahasan sebelumnya, bahwa sejak masa kerajaan, kesultanan, melewati masa kemerdekaan, bahkan sampai pasca reformasi pola perkembangan hukum adat Bima terdapat sintesis terjadi ketika hukum adat dan hukum Islam berjumpa dan saling mengisi, transplantasi terjadi ketika hukum kolonial memangkas kewenangan pranata lokal yang menyebabkan terjandinya kekosongan hukum, terintegrasi ketika terjadi politik hukum penyeragaman lewat kodifikasi dan univikasi, pasca reformasimasi kearifan lokal terangkat lewat kebijakan perda, kondisi ini seklaigus memperlitkan pola positivisasi sekaligus sebagai kecenderungan perkembangan hukum adat Bima pasca reformasi, lalu terakhir ada komunitas masyarakat Donggo yang konsisten menjalankan hukum adat yang di bangun lewat konsesnsus yang berjalan secara alamiah dengan aparat penegak hukum dan juga akibat langsung dari perawatan lewat politik lokal pemda pasca reformasi, kondisi ini juga mmperlihatkan pola perkembangan hukum adat Bima yang ter-konservasi, sekaligus sebagai kecenderungannya pasca reformasi.

\section{Daftar Pustaka}

Rahadjo, Satjipto, 2007, Biarkan Hukum Mengalir: Catatan Kritis Tentang Pergulatan Manusia dan Hukum, Jakarta: Penerbit Kompas.

Satjipto, Rahardjo, Dalam Khudzaifah Dimyati (ed), 2004, Ilmu Hukum: Pencarian Pembebasan dan Pencerahan, Surakarta: Muhammadiyah Univesity Press Ubiversitas Muhammadiyah Surakarta.

Wignjosoebroto, Soetandyo, 1995, Dari Hukum Kolonial Ke Hukum Nasional: Dinamika SosialPolitik Dalam Perkembangan Hukum Indonesia, Jakarta: PT. Raja Grafindo Persada.

Dimyati, Khudzaifah, 2010, Teorisasi Hukum: Studi Tentang Perkembangan Pemikiran Ilmu Hukum Di Indonesia 1945-1990, Yogyakarta: Genta Publishing.

Satjipto, Rahadjo, 2010, Penegakan Hukum Progresif, Jakarta: Kompas.

Samekto, FA. Adji, 2008, Justice Not For All: Kritik Terhadap Hukum Modern Dalam Perspektif Studi Hukum Kritis, Yogyakart: Genta Press.

Sofian, Effendi, 2010, Reformasi Tata Kepemerintahan: Menyiapakan Aparatur Negara Untuk Mendukung Demokratisasi Politik dan Ekonomi Terpadu, Yogyakarta: Gajah Mada University Press. 
W, Soetandyo, 1974, Penelitian Hukum: Sebuah Tipologi, Majalah Masyarakat Indonesia Tahun Ke1, No, 1974.

Huijbers, Theo, 1982, Filsafat Hukum Dalam Lintasan Sejarah, Yogyakarta: Kanisius.

Syarifuddin, Jurdi, 2007, Islam, Masyarakat Madani Dan Demokrasi Di Bima: Membangun Demokrasi Kultural Yang Berbasis Religius, Yogyakarta: CNBS.

Hilir, Ismail Muhammad, 2004, Menggali Pusaka Terpendam: Butir-Butir Muatiara Budaya Mbojo, Bima: Makalah tidak diterbitkan.

Abdullah, Abdul Gani, 2004, Peradilan Agama Dalam Pemerintahan Islam Di Kesultannan Bima (1947-1957), Mataram: Lengge.

Davidson, Jamie S. dan David Henley, In the Name of Adat: Regional Perspectives on Reform, Tradition, and Democracy in Indonesia, Modern Asian Studies, 2008, hlm. 815-852. Dalam Cambridge University Press, Printed in the United Kingdom, http://search. proquest.com, di akses pada tanggal, 10 Mei 2012.

Jawahir, Thontowi, 2007, Hukum Kekerasan Dan Kearifan Lokal Penyelesaian Sengketa Di Sulawesi Selatan, Yogyakarta: Pustaka Fahima. 